\title{
Establishing a genomic database for the medicinal plants in the Brazilian Pharmacopoeia
}

\author{
Guan-Ru Zhou ${ }^{1,2+}{ }^{,}$Bao-Sheng Liao ${ }^{2 \dagger}$, Qiu-Shi Li ${ }^{2}$, Jiang $\mathrm{Xu}^{2^{*}}$ and Shi-Lin Chen ${ }^{2 *}$
}

\begin{abstract}
Background: Brazil is exceptionally abundant in medicinal plant resources and has a rich ethnopharmacological history. Brazilian Pharmacopoeia (BP) acts as a national standard that regulates drug quality and has six published editions. Recent genomic approaches have led to a resurgence of interest in herbal drugs. The genomic data of plants has been used for pharmaceutical applications, protecting natural resources, and efficiently regulating the market. However, there are few genomic databases specifically for medicinal plants, and the establishment of a database that focuses on the herbs contained in the BP is urgently required.

Methods: The medicinal plant species included in each edition of the BP were analyzed to understand the evolution of the Brazilian herbal drugs. The data of 82 plants in the BP were collected and categorized into four sections: DNA barcodes, super-barcodes, genomes, and sequencing data. A typical web server architecture pattern was used to build the database and website. Furthermore, the $\mathrm{cp}-\mathrm{Gs}$ of the Aloe genus in the database were analyzed as an illustration.
\end{abstract}

Results: A new database, the Brazilian Pharmacopoeia Genomic Database (BPGD) was constructed and is now publicly accessible. A BLAST server for species identification and sequence searching with the internal transcribed spacer 2 (ITS2), the intergenic region ( $p s b \mathrm{~A}-\mathrm{trnH})$ ), and the chloroplast genome (cp-G) of Brazilian medicinal plants was also embedded in the BPGD. The database has 753 ITS2 of 76 species, 553 psbA-trnH and 190 genomes (whole genome and chloroplast genome) of 57 species. In addition, it contains 37 genome sequence data sets of 24 species and 616 transcriptome sequence data sets of 34 species and also includes $187 \mathrm{cp}$-Gs representing 57 medicinal species in the BP. Analyses of the six cp-Gs of three Aloe species identified the variable regions in the $\mathrm{cp}-\mathrm{Gs}$. These can be used to identify species and understand the intraspecific relationships.

Conclusions: This study presents the first genomic database of medicinal plants listed in the latest BP. It serves as an efficient platform to obtain and analyze genomic data, accelerate studies regarding Brazilian medicinal plants and facilitate the rational development on their market regulation.

Keywords: Genome, Medicinal plants, Brazilian Pharmacopoeia, DNA barcodes, Chloroplast genome, Herbgenomics

*Correspondence: jxu@icmm.ac.cn; slchen@icmm.ac.cn

${ }^{\dagger}$ Guan-Ru Zhou and Bao-Sheng Liao contributed equally to this work

${ }^{2}$ Institute of Chinese Materia Medica, China Academy of Chinese Medical Sciences, Beijing 100700, China

Full list of author information is available at the end of the article

\section{Background}

Medicinal plants are sources of phytochemicals that play vital roles in disease prevention and treatment. These sources are inexpensive and readily available and have been used in developed and lesser developed countries $[1,2]$. The discovery of Salicin (analgesic and antipyretic) by Rafaele Piria, in 1832, from Salix alba [3] is original author(s) and the source, provide a link to the Creative Commons licence, and indicate if changes were made. The images or other third party material in this article are included in the article's Creative Commons licence, unless indicated otherwise in a credit line to the material. If material is not included in the article's Creative Commons licence and your intended use is not permitted by statutory regulation or exceeds the permitted use, you will need to obtain permission directly from the copyright holder. To view a copy of this licence, visit http://creativecommons.org/licenses/by/4.0/. The Creative Commons Public Domain Dedication waiver (http://creativeco mmons.org/publicdomain/zero/1.0/) applies to the data made available in this article, unless otherwise stated in a credit line to the data. 
considered a milestone in the development of the global pharmaceutical industry. Since then, medicinal plants have gained considerable importance as sources of bioactive phytochemicals for drug discovery $[4,5]$. It has been estimated that approximately $30 \%$ of therapeutic drugs are derived from natural resources, particularly plants and microorganisms [6, 7]. In addition, the completion of the Human Genome Project has opened a new chapter in understanding and treating human diseases, initiating and gradually deepening research of herbs at the genomic level [8]. Furthermore, Tu Youyou's discovery of artemisinin from the plant Artemisia annua to treat malaria also demonstrates the potential role of medicinal plants [9].

Herbal medicines in the Latin America came into contact with other medical traditions at the beginning of the sixteenth century, introduced throughout the Conquest and European colonial expansion. Within a dominant sociopolitical framework, the folk herb traditions were fused with other medical cultures and syncretized by religious doctors and other various social workers of certain regional public health systems [10]. During the next three centuries, the historical relationships between native medical traditions in Latin America and the medical cultures of other continents, created a particularly rich ethnomedicinal foundation [11] and continually impacted the national health system of Latin American countries.

Brazil is an ideal country in Latin America that has established itself in public health, emphasizing the application and development of medicinal plants and their derivatives. Brazil has the world's largest share of biodiversity (15-20\%), and most of this biodiversity has not been explored, offering plenty of scope for herbal medicine development $[3,12]$. The diverse Brazilian culture contributes mainly to the use of herbal medicines. Besides, approximately 305 ethnic groups, speaking 274 languages [13], have thousands of years of ethnopharmacological history [14]; approximately 1000 plant species have been used as Amazon's traditional medicine $[15,16]$. Additionally, the Portuguese, who colonized Brazil between 1500 and 1822, brought herbs from other parts of the world instead of exploring the native medicinal plants [17]. The traditional herbal medical system with the combined knowledge of the indigenous people, Europeans, and Africans has led to the development of botanical medicines [18]. Consequently, Brazil has become the biggest pharmaceutical market and the only country in Latin America ranked amongst the top pharmaceutical markets worldwide [19]. As the standard publications regulating the quality of drugs, the pharmacopoeias make the quality standards obligatory, ensuring consistency in medicines approved by representatives of specific political units and representing the local progress in related scientific fields [20]. The latest (sixth) edition of $\mathrm{BP}$ has revoked all other editions; serves as the core edition of future editions through constant review, seeking to emerge as an international standard. Currently, the Brazilian Pharmacopoeia Commission is an observer for the European and International pharmacopoeias and has a mutual acknowledgement with the Argentine Pharmacopoeia [21]. It will also help guide proposals for the joint development of pharmacopoeias with countries on the South America continent. As a national pharmacopoeia in the Portuguese language, the BP also has an influence on other regions, including Macau, an area that could be a center for medicinal plant development, that integrates Brazilian and Chinese herbal knowledge.

New proteomic and genomic technologies have led to a resurgence of interest in natural products in academia and pharmaceutical organizations [22, 23]. DNA barcode is a short DNA fragment that is different between species [24], and it provides a practical solution for identifying species. In addition, the optimal combination of single-locus barcodes with chloroplast genome (superbarcodes) provides a new method for efficient plant identification [25]. Thus, a database that integrates DNA barcodes and organelle genomes may solve the increasing challenges in plant identification, not just in Brazil, but globally. With the development of sequencing technology and synthetic biology, the transcriptome and genome of plants have been sequenced and used to synthesize the desired compounds by bacterial engineering [26]. For example, ingredients with high medicinal activity, such as artemisinin [27, 28] and paclitaxel [29], have been extracted from medicinal plants. With the help of omics data, the decomposition of biosynthetic pathways of drug compounds has also entered the fast lane [30,31].

Quality germplasm resources are the key to the generation of omics data. However, various wild resources of plant species have been endangered due to habitat destruction and extensive exploitation and utilization [32-34]. Molecular-marker-assisted breeding based on genomic data can enrich germplasm resources and protect wild resources efficiently [35]. Cultivation of wild medicinal plants has become an inevitable trend of sustainable development [36]. Representative examples of comprehensive omics databases to assist crop breeding are available for rice [37], maize [38], and wheat [39], but none exist for herbs. A database that collects omics data of medicinal plants could accelerate the molecular breeding of elite cultivars.

A genomic database is a warehouse that organizes, stores, and manages a variety of genomic data. There are three public, comprehensive genomic databases available: the National Centre for Biotechnology Information $(\mathrm{NCBI})$, the European Institute of Bioinformatics 
(EBI), and the DNA Database of Japan (DDBJ). With the rapid increase in the volume and complexity of biological data, these databases play important roles in advancing molecular research [40]. Several studies have published genomic data of medicinal plants; however, problems such as different research team hosts, inconsistent data formats, and unstable web services have brought challenges for the utilization of herb genomic data. Additionally, due to the continuous improvements in genome assembly and species sequencing, the number of genome assemblies within a single species is also increasing $[30,41]$. The use of these multiple versions of a genome assembly can be confusing and time-consuming. Therefore, genomic data need to be organized and displayed for further use.

In the present study, the Brazilian Pharmacopoeia Genomic Database (BPGD) [42], a database of the BP medicinal plants containing genetic information, that includes the genome, transcriptome, $\mathrm{cp}-\mathrm{G}$, and DNA barcodes, is built. The BPGD will provide a valuable resource for accelerating genome research and the molecular breeding of medicinal plants in Brazil.

\section{Methods}

\section{Data collection and curation workflow}

A schematic overview of the BPGD construction pipeline is shown in Fig. 1. The medicinal plant species of the BP edition were analyzed to understand the changes in the numbers and species of herbal medicines in Brazil. The statistical data of the medicinal plants were collected and categorized from all six editions of the BP. The categories included Latin names, Chinese names, families, relative monographs, occurrence numbers, native or exotic status and other parameters. Details regarding the plant species in the first four editions were collected from a previous work [43], while those in the last two editions were collected and categorized. Latin names that appeared in the $\mathrm{BP}$ were adapted according to the monograph description while the native geographical distribution of the plant taxa were adapted according to several modern floras, such as the Flora Reipublicae Popularis Sinicae [44], and the Flora do Brasil 2020 [45].

The genomic data were collected from public databases. The ITS2 and psbA-trnH sequences available in the NCBI database [46] were linked to the BPGD. The nuclear genomes were downloaded from the NCBI genome database. The majority of raw data were collected from the NCBI Sequence Read Archive (SRA) database [46] and a few from the China National GeneBank database (CNGB) [47]. The uploaded data were categorized into four sections: DNA barcodes, super-barcodes, genomes, and sequencing data sets.
Data of 82 medicinal plants with definite Latin names that were compiled from the plant monographs in the latest (sixth) edition of the $\mathrm{BP}$, were incorporated into the BPGD. Currently, the BPGD (v1.0) has 753 ITS2 of 76 species, 553 psbA-trnH and $187 \mathrm{cp}-\mathrm{Gs}$ of 57 species, the optimal nuclear genomes of three species, and 37 raw genome sequencing data of 24 species, whose assembled nuclear genome data have not been published. In addition, it contains 616 raw transcriptome sequencing data of 34 species.

The cp-Gs were assembled, following the methods described in a previous study [48]. All Aloe cp-Gs were aligned using the MAFFT program [49]. The sequence identity in a $50 \mathrm{bp}$ window of the alignment was calculated. The same genes from different $\mathrm{cp}$-Gs were pairwise aligned using Clustal Omega [50], and the pairwise genetic distance was calculated using the EMBOSS program distmat [51] with the default parameters.

\section{Database implementation}

The BPGD was constructed based on the typical web server architecture pattern, LNMP, including the Linux operating system, the Nginx web server with high-performance HTTP and reverse proxy servers, MySQL database server and $\mathrm{H} 2$ data management system, and the PHP programming language. A BLAST server was also established to identify the Brazilian medicinal plants based on ITS2, $p s b \mathrm{~A}-\operatorname{trn} \mathrm{H}$, and cp-G.

\section{Results \\ Medicinal plants recorded in the Brazilian Pharmacopoeia (BP)}

This study explored the history and development of medicinal plants in the BP (Fig. 2). A total of 200 plants were recorded only in the first edition; 44 in the first and second editions, and 43 in the fifth and sixth editions, which were not included in any other editions. In addition, only three medicinal plant species were recorded in all of the six BP editions and 14 in five editions (Fig. 2A). Additionally, consistent with the earlier editions [21, 52-54], the exotic species were more than native species in the sixth edition (Fig. 2B), indicating the broader applications of non-native herbal drugs in Brazil due to the excellent documentation of quality control [55]. However, a combination of the previous work [21, 52-54] and the data from the last two editions, shows that the number of native plants has risen since the fourth edition of the BP. An analysis of 22 plant families, with most species recorded in the BP history (Fig. 2C), pointed out that eight families alone (Fig. $2 \mathrm{C}$; eight from left) comprised more than $50 \%$ of the species in the BP. Thus, the $\mathrm{BP}$ analysis confirmed that research on medicinal plants in Brazil is constantly improving. 


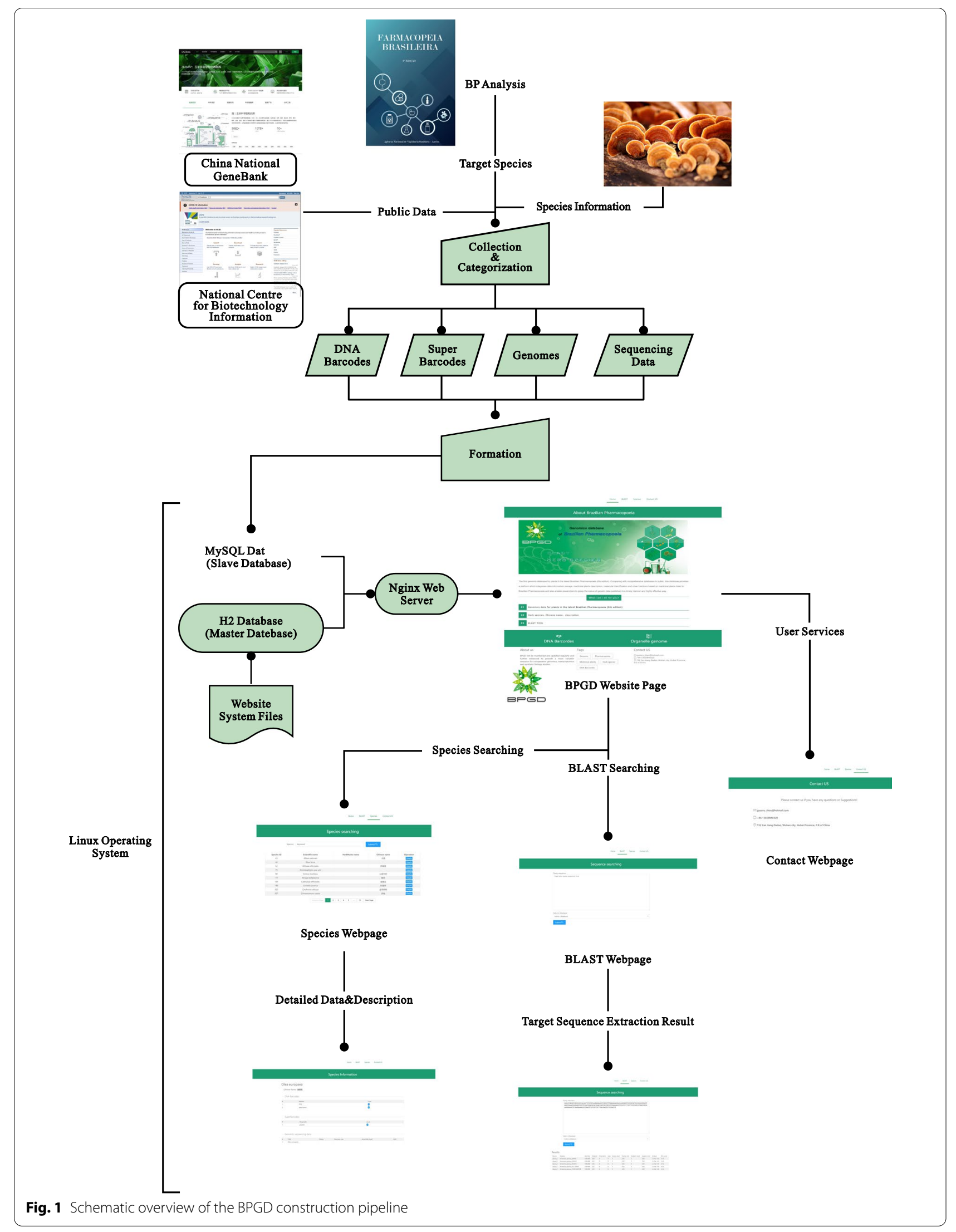




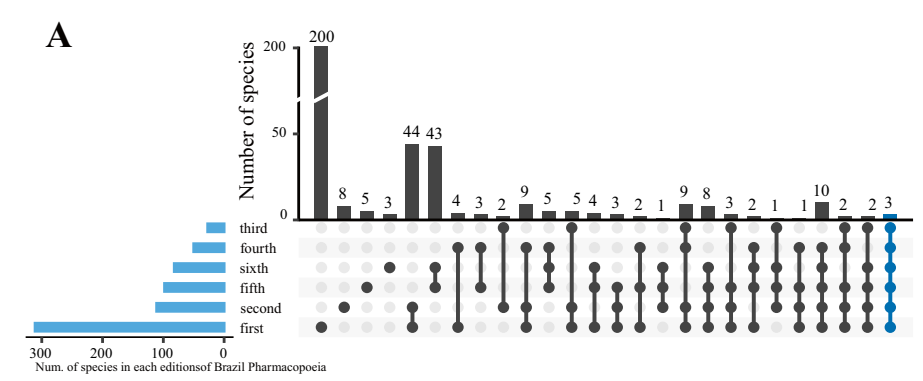

\section{B}

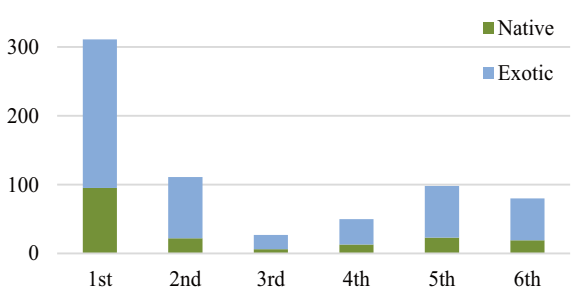

C
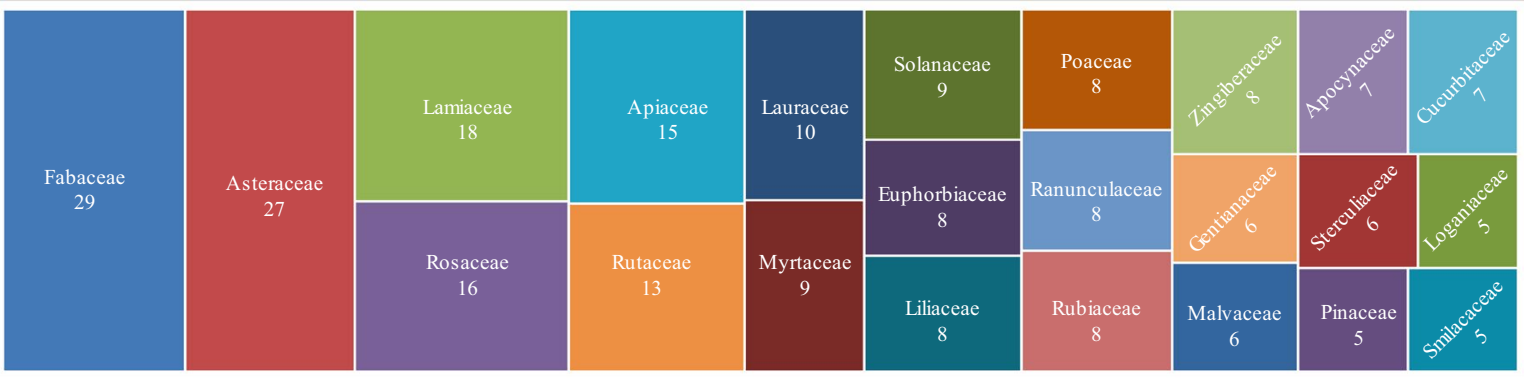

Fig. 2 Summary of medicinal species recorded in each edition of the BP. A Medicinal species information from different editions of the BP. The dot represents the horizontally aligned edition of the BP, and the line connecting the dots represents the species intersection of the different editions of the BP. B Native and exotic species in six editions of the BP. C Twenty-two families with the most species recorded in the BP publication history. The area of the rectangle represents the number of species in the family

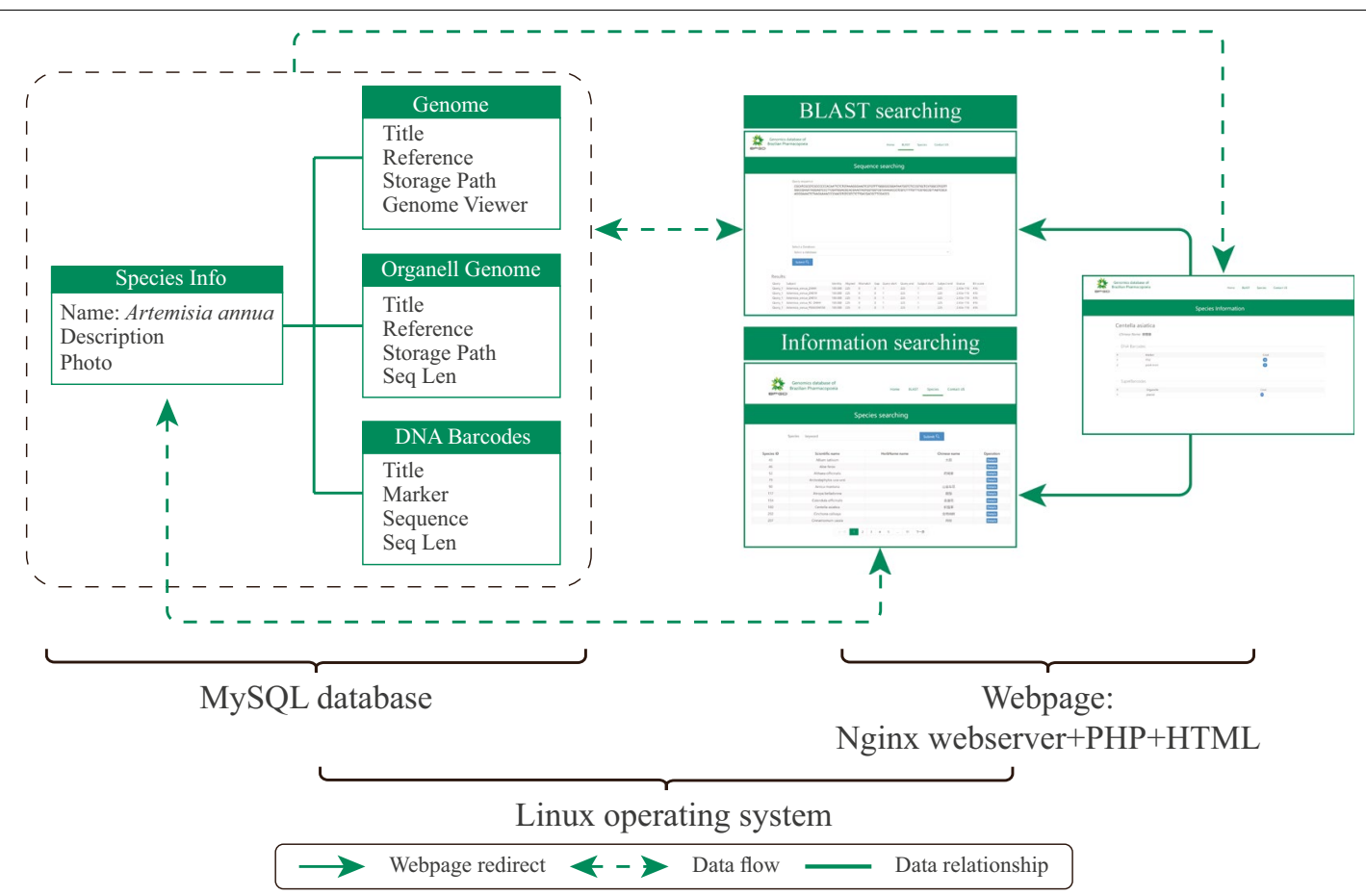

Fig. 3 The BPGD structure and the core web pages 


\section{Structure of the database}

The BPGD can be publicly accessed via http://www. bpgenome.com. The database and its web pages are userfriendly (Fig. 3). The BPGD homepage provides the latest information on the compiled BP medicinal plants. The database homepage has a navigation menu consisting of four entries: "Home", "Blast", "Species", and "Contact us". The homepage also displays a brief introduction and the data collection status. A BLAST tool containing with ITS2, psbA-trn $\mathrm{H}$, and $\mathrm{cp}-\mathrm{G}$ sequences provided under the "Blast" entry on the homepage enables search against the genomes and transcriptomes (Additional file 2: Figure S1). Users can view and download the hits from the "Results" page and it shows the species with the highest identity to the query sequence. Through the "Species" page, users can browse the species list and search specific plants using the Latin name keyword. Each plant comes with a "details" tab and the detailed data consist of foursections: DNA barcodes, super barcodes, genomes, and sequencing data sets. Under the "ITS2" and "psbAtrn $\mathrm{H}$ " gateways, twotypes of DNA barcoding nucleotide sequences are available in the Fasta format. Additionally, the optimal nuclear genome data and the links to the original and other assembled versions of the genome can be obtained under the "Genome" gateway.

\section{Characteristics of the collected cp-Gs in the BPGD}

The chloroplast genome (cp-G) has a suitable length and sufficient variable sites between species, and these sites have been used as super-barcodes to identify plant species [25]. In total, $187 \mathrm{cp}-\mathrm{Gs}$ representing 57 medicinal plant species of the BP were collected and stored in the BPGD (Table 1, Additional file 1: Table S1). Babosa (Aloe vera L.) is a common species in northeastern Brazil. Its leaves, extracts, and resins have antibacterial, anti-inflammatory, and healing properties and are used to treat liver and stomach diseases [56]. Six cp-Gs of threeAloe species (A. vera, A. maculata, and A. barbadensis; two cp-Gs from each) in the BPGD were analyzed to identify the variable regions in the $\mathrm{cp}$-Gs of these species. The most variable region in the $\mathrm{cp}-\mathrm{Gs}$ was located in the large single-copy (LSC) region, and the most variable gene was NADH dehydrogenase F (ndhF; Fig. 4). The variable region could be used to identify species and understand the intraspecific relationships of the Aloe genus.

\section{Discussion}

Brazil is endowed with unique medicinal plant resources, that play a crucial role in sustaining human health. The history of the BP has been well explained and contains data that help us understand the evolution of medicinal plants. The first edition of the BP, containing a list
Table 1 Statistics of chloroplast genomes stored in BPGD

\begin{tabular}{|c|c|c|}
\hline Family & Genera & Cp-count \\
\hline Malvaceae & Althaea, Gossypium, Theobroma & 21 \\
\hline Rutaceae & Citrus & 15 \\
\hline Zingiberaceae & Curcuma, Zingiber & 14 \\
\hline Asteraceae & Helianthus, Matricaria & 13 \\
\hline Fabaceae & Glycyrrhiza, Stryphnodendron & 12 \\
\hline Solanaceae & Atropa, Datura, Hyoscyamus & 11 \\
\hline Myrtaceae & $\begin{array}{l}\text { Corymbia, Eucalyptus, Eugenia, Mela- } \\
\text { leuca, Psidium, Syzygium }\end{array}$ & 11 \\
\hline Caprifoliaceae & Sambucus, Valeriana & 9 \\
\hline Apiaceae & $\begin{array}{l}\text { Anethum, Centella, Coriandrum, Foenicu- } \\
\text { lum }\end{array}$ & 8 \\
\hline Lauraceae & Cinnamomum, Persea & 8 \\
\hline Rosaceae & Crataegus, Prunus & 7 \\
\hline Oleaceae & Olea & 6 \\
\hline Passifloraceae & Passiflora & 6 \\
\hline Amaryllidaceae & Allium & 5 \\
\hline Quillajaceae & Quillaja & 4 \\
\hline Poaceae & Cymbopogon & 3 \\
\hline Ranunculaceae & Hydrastis & 3 \\
\hline Phyllanthaceae & Phyllanthus & 3 \\
\hline Plantaginaceae & Plantago & 3 \\
\hline Orchidaceae & Vanilla & 3 \\
\hline Asphodelaceae & Aloe & 2 \\
\hline Schisandraceae & Illicium & 2 \\
\hline Lamiaceae & Mentha, Thymus & 2 \\
\hline Sapindaceae & Paullinia & 2 \\
\hline Apocynaceae & Rauvolfia & 2 \\
\hline Polygonaceae & Rheum & 2 \\
\hline Hippocastanaceae & Aesculus & 1 \\
\hline Ericaceae & Arctostaphylos & 1 \\
\hline Sterculiaceae & Cola & 1 \\
\hline Hamamelidaceae & Hamamelis & 1 \\
\hline Pedaliaceae & Harpagophytum & 1 \\
\hline Convolvulaceae & Operculina & 1 \\
\hline Monimiaceae & Peumus & 1 \\
\hline Anacardiaceae & Schinus & 1 \\
\hline Loganiaceae & Strychnos & 1 \\
\hline
\end{tabular}

of plant species that are used in conventional and traditional medicine, is still considered outstanding [57]. This edition also includes 196 monographs of the native herbs that do not exist in any other editions [58], and $42 \%$ of medicinal products related to plants [59]. In the early 20th century, the name of traditional Brazilian medicine was generated based on a combination of indigenous knowledge and understanding of the information brought by the Portuguese, Spaniards, and Africans [60]. The Brazilian society transformed severely [61] after the release of the first edition. Sometime in 1940, due to the 

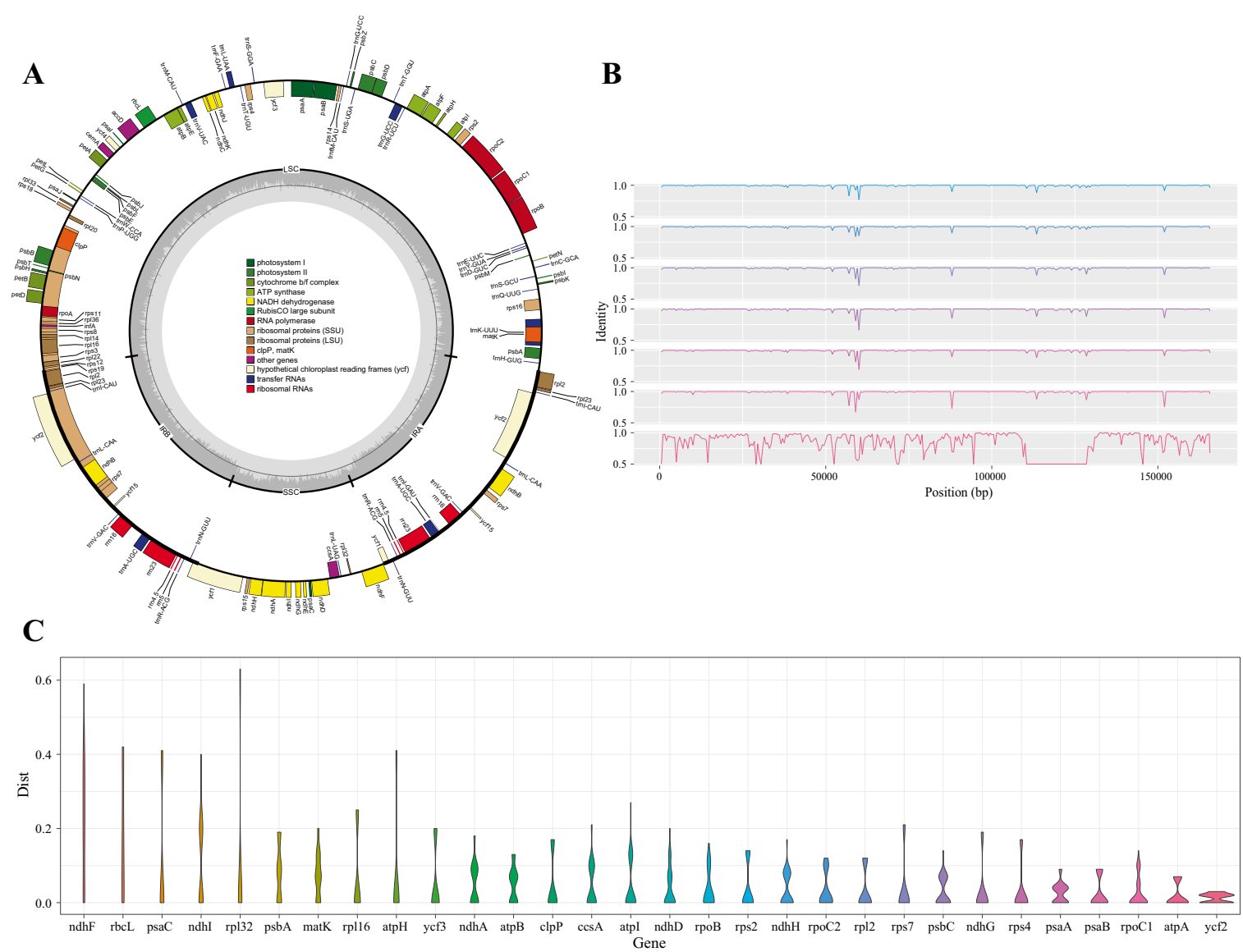

Fig. 4 Chloroplast genome analysis. A Chloroplast genome of Aloe vera. B Whole-sequence alignment of three Aloe species, using Belamcanda chinensis as the outgroup. $\mathbf{C}$ The pairwise distance for each gene in the chloroplast genome of three Aloe species

growth of the global pharmaceutical industry and lack of pharmacological knowledge on the efficacy and toxicity of medicinal plants [62, 63], Brazilians reorganized the pharmaceutical industry to produce drug formulas that utilized imported materials instead of native ones $[64,65]$. Later, during World War II, synthetic medicines strongly substituted the traditional medicinal plants [64, 66, 67], which was evident in the subsequent two BP editions. The monographs of plants reduced from 713 in the first edition to 205 in the second edition and 23 in the third edition [52, 68]. Several studies have shown that deforestation affects the natural ecosystem and the devaluation of phytotherapy has threatened medicinal plants and medical knowledge [18, 69, 70]. However, the number of medicinal plants began to grow as the public started favoring phytotherapy. Consequently, the monographs of medicinal plants increased to $17 \%$ in the fourth edition $[52,57,71]$ and $25 \%$ in the fifth edition [58]. Finally, the sixth edition (2019) included a section dedicated to medicinal plants with 149 monographs of plants and plant derivatives. Over nine decades since the first BP was published, the change in the medicinal plants listed in the BP was enormous and the increasing trend of herbal drug use reflected the latest three editions of the BP indicates the recovery of phytotherapy. However, considering the Brazilian biodiversity and the rich phytotherapy history, the patents and medicines based on the BP are few [3]. The combination of traditional herbal knowledge with cutting-edge genomic research methods is of great significance for the understanding and application of medicinal plants in Brazil. Millions of locals would benefit from the use of medicinal plants in health care [72]. The expansion of phytotherapy based on advanced approaches can improve the quality of life of people and contribute to the economic and technological development of society.

Pathogenic microbes, toxic compounds [73, 74], adulterations, and counterfeit drugs [75-78] have raised significant concerns regarding the quality and safety of herbal medicines. The classical analytical procedures provided by the monographs in the BP have projected the difficulties in solving these complex problems related 
to both exotic and native herbs. Additionally, the natural ecosystem destruction observed in Brazil $[67,79,80]$ demands the conservation of Brazilian medicinal plant resources. Because of the global impact of genomics and due to the increasing damage to the domestic ecological environment, the local government and scientists have also made efforts to develop genomics. The Brazilian government began constructing a genetic database in 1984. The Brazilian government organization for Agricultural Research (EMBRAPA) created the National Genetic Resources and Biotechnology Research Center (CENARGEN), aiming at managing the activities related to genetic resources in Brazil [16].

Research on medicinal plants has recently entered the "herbgenomics" era with the development of advanced technologies, especially genomics, transcriptomics, and proteomics. Omics-based analysis has helped us to understand the genetic makeup of herbal medicines revealing their origin, quality, synthesis, safety, and conservation requirements. These technologies will promote the sustainable development of medicinal plants, thereby progressing in human health [81]. The emergence of herbgenomics has enabled systematic research on plantbased medicines from a genetic perspective [8]. Furthermore, molecular-assisted breeding can accelerate the herb breeding progress and protect wild resources with the help of genomics data, for instance, Panax notoginseng [82] and Perilla frutescens [83].

A publicly accessible database will act as the key hub to efficiently access and interpret the available data sets. To support researchers in handling the rapidly changing data, the development of databases is crucial and challenging. First, genomic data need to be further supplemented. The BPGD (V1.0) collected a portion of the plant species within the latest BP, and the acquisition of more comprehensive genomic data from other medicinal plants in various BP editions will be a challenge, due to difficulties in sample collection and identification, especially for native plant species. Furthermore, the function of the database requires further improvements, and more tools will be developed to meet the requirements of diverse herb studies. An online community will be constructed in order to enrich the data resources and encourage knowledge sharing. Finally, as the database and website are newly developed, there is an uncertainty associated with it as users are only just becoming aware of it. It is our belief that with time as the BPGD becomes more established through development, users will become more familiar with it, engage in the initiative and become willing to use the data and share resources. Several other genomic databases of other well-known pharmacopoeias are currently under construction in our research group, and the completion of the BPGD is the first wave. The BPGD will keep updating data of medicinal plants, and expand to include other data of medicinal plant species in Latin America as a supplement and for possible future applications.

\section{Conclusions}

The database, the BPGD, acts as a bridge that connects the cutting-edge genetic approaches and findings with Brazilian medicinal plants and ethnopharmacy. The BPGD is the first database established that has collected genomic data (DNA barcoding, transcriptome, nuclear genome, and $\mathrm{cp}-\mathrm{G}$ ) of medicinal plants listed in the BP. The database has a ready-to-use data storage function and includes the description, molecular identification, and functions of medicinal plants listed in the BP. The BPGD provides a platform for biological researchers to access the published genetic data quickly and effectively, accelerating research on Brazilian medicinal plants and facilitating the rational development of their market regulation. The BPGD consists of more than 70\% of medicinal plant species from the last edition of the BP and will be regularly updated and maintained to provide more comprehensive data and an enhanced user experience.

\begin{abstract}
Abbreviations
BPGD: Brazilian Pharmacopoeia Genomic Database; BLAST: Basic Local Alignment Search Tool; BP: Brazilian Pharmacopoeia; NCBI: National Centre for Biotechnology Information; EBI: European Institute of Bioinformatics; DDBJ: DNA Database of Japan; LNMP: Nginx, PHP, MySQL, phpMyAdmin; HTTP: Hyper Text Transfer Protocol; PHP: Hypertext Preprocessor; ITS: Internal transcribed spacer; NCBI SRA: National Centre for Biotechnology Information, Sequence Read Archive database; CNGB: China National Gene Bank database; LSC: Large single-copy; ndhF: NADH dehydrogenase F; MAFFT: Multiple Alignment using Fast Fourier Transform; EMBOSS: European Molecular Biology Open Software Suite.
\end{abstract}

\section{Supplementary Information}

The online version contains supplementary material available at https://doi. org/10.1186/s13020-021-00484-5.

Additional file 1: Table S1. Summary of Cp genomes in the BPGD.

Additional file 2: Figure S1. The tutorial of the species identification function of the BPGD.

\section{Acknowledgements}

This work was supported by the National Key R\&D Program of China from the Ministry of Science and Technology of China (Grant No. 2019YFC1711100), the National Natural Science Foundation of China and Karst Science Research Center of Guizhou Province (U1812403-1), and the Special Foundation for National Science and Technology Basic Research Program of China (2018FY100701)

\section{Authors' contributions}

JX and SLC designed the research; GRZ participated in the data collection and the database construction; BSL provided the technical support and analyzed the data; QSL provided the advices for the study; GRZ and BSL wrote the manuscript. All authors read and approved the final manuscript. 


\section{Funding}

Not applicable.

\section{Availability of data and materials}

The data sets used and/or analyzed during the current study are available from the corresponding author upon reasonable request.

\section{Declarations}

Ethics approval and consent to participate

Not applicable.

\section{Consent for publication}

Not applicable.

\section{Competing interests}

The authors declare that they have no competing interests.

\section{Author details}

${ }^{1}$ Institute of Pharmacy, Hubei University of Chinese Medicine, Wuhan 430000, China. ${ }^{2}$ Institute of Chinese Materia Medica, China Academy of Chinese Medical Sciences, Beijing 100700, China.

Received: 18 June 2021 Accepted: 29 July 2021

Published online: 05 August 2021

\section{References}

1. Fürst R, Zündorf I. Evidence-based phytotherapy in Europe: where do we stand. Planta Med. 2015;81(12-13):962-7.

2. De Oliveira DR. A consolidação das práticas integrativas e complementares no século 21. VITTALLE-Revista de Ciências da Saúde. 2018;30(1):7-8.

3. Dutra RC, et al. Medicinal plants in Brazil: pharmacological studies, drug discovery, challenges and perspectives. Pharmacol Res. 2016;112:4-29.

4. Ricardo L, Goulart E, Brandão M. Plantas medicinais da Bacia do Rio das Velhas: avaliação das condições para produção e uso em saúde pública. Revista Brasileira de Plantas Medicinais. 2015;17(3):398-406.

5. Azwanida N. A review on the extraction methods use in medicinal plants, principle, strength and limitation. Med Aromat Plants. 2015;4(196):2167-0412.

6. Newman DJ, Cragg GM. Natural products as sources of new drugs over the 30 years from 1981 to 2010. J Nat Prod. 2012;75(3):311-35.

7. Cragg GM, Newman DJ. Natural products: a continuing source of novel drug leads. Biochim Biophys Acta (BBA) Gen Subj. 2013;1830(6):3670-95.

8. $\mathrm{Hu} \mathrm{H}$, et al. Herbgenomics: a stepping stone for research into herbal medicine. Sci China Life Sci. 2019;62(7):913-20.

9. Shi-lin C, et al. Highlights on the progress of traditional Chinese medicine and natural drugs during 2015-2020. Acta Pharm Sin. 2020;55(12):2751-76.

10. Pedersen D, Baruffati V. Health and traditional medicine cultures in Latin America and the Caribbean. Soc Sci Med. 1985;21(1):5-12.

11. Harrison IE, Cosminsky S. Traditional medicine: implications for ethnomedicine, ethnopharmacology, maternal and child health, mental health, and public health: an annotated bibliography of Africa, Latin America, and the Caribbean, vol. 147. New York: Taylor \& Francis; 1976.

12. Gurib-Fakim A. Medicinal plants: traditions of yesterday and drugs of tomorrow. Mol Aspects Med. 2006;27(1):1-93.

13. IBGE. Censo demográfico: 2010: características gerais dos indígenas: resultados do universo. 2010.

14. Calixto JB. Efficacy, safety, quality control, marketing and regulatory guidelines for herbal medicines (phytotherapeutic agents). Braz J Med Biol Res. 2000;33(2):179-89.

15. Wolters B. Jarhtausend vor Kolumbus: Indianische kulturpflanzen und Arzneidrogen. Deutsche Apotheker Zeitung. 1992;40:1-10.

16. Vieira R, Skorupa L. Brazilian medicinal plants gene bank. In: WOCMAP I-medicinal and aromatic plants conference: part 4 of 4 330. 1992.

17. Marchant A. Dom Joao's botanical garden. Hisp Am Hist Rev. 1961;41(2):259-74.
18. Bruning MCR, Mosegui GBG, Vianna CMdM. A utilização da fitoterapia e de plantas medicinais em unidades básicas de saúde nos municípios de Cascavel e Foz do Iguaçu-Paraná: a visão dos profissionais de saúde. Ciência \& saúde coletiva. 2012;17:2675-2685.

19. Ríos AM. Pharmaceutical industry in Brazil—statistics \& facts. Statista. 2020.

20. Urdang $\mathrm{G}$. The development of pharmacopoeias; a review with special reference to the pharmacopoea internationalis. Bull World Health Organ. 1951:4(4):577-603.

21. Anvisa ANdVS. Farmacopeia Brasileira 6a edição. 2019.

22. Harvey AL, Edrada-Ebel R, Quinn RJ. The re-emergence of natural products for drug discovery in the genomics era. Nat Rev Drug Discov. 2015:14(2):111-29.

23. Sheridan C. Recasting natural product research. Nat Biotechnol. 2012;30(5):385-7.

24. Hebert PD, et al. Biological identifications through DNA barcodes. Proc $R$ Soc Lond. 2003;270(1512):313-21.

25. Li $X$, et al. Plant DNA barcoding: from gene to genome. Biol Rev. 2015;90(1):157-66.

26. Wang $X$, et al. HMOD: an omics database for herbal medicine plants. Mol Plant. 2018;11(5):757-9.

27. Callaway E, Cyranoski D. Anti-parasite drugs sweep Nobel prize in medicine 2015. Nat News. 2015;526(7572):174.

28. Klayman DL. Qinghaosu (artemisinin): an antimalarial drug from China. Science. 1985;228(4703):1049-55

29. Weaver BA. How taxol/paclitaxel kills cancer cells. Mol Biol Cell. 2014;25(18):2677-81.

30. Xu J, et al. Panax ginseng genome examination for ginsenoside biosynthesis. Gigascience. 2017;6(11):1-15.

31. Guo L, et al. The opium poppy genome and morphinan production. Science. 2018:362(6412):343-7.

32. Zhibin G, Zailin L, Er L. A rare and endangered medicinal plant: Dendrobium nobile. Chin Wild Plant Resour. 2002;4:011.

33. Bantawa P, et al. Status and conservation threats of Picrorhiza scrophulariiflora Pennell. (Scrophulariaceae): an endangered high valued medicinal plant of Indo-China Himalayan region. Bioremediat Biodivers Bioavailab. 2009;3:15-22.

34. Chik W-l, et al. Saussurea involucrata: a review of the botany, phytochemistry and ethnopharmacology of a rare traditional herbal medicine. J Ethnopharmacol. 2015;172:44-60.

35. Bevan MW, et al. Genomic innovation for crop improvement. Nature. 2017:543(7645):346-54

36. Cordell GA. Ecopharmacognosy and the responsibilities of natural product research to sustainability. Phytochem Lett. 2015;11:332-46.

37. Woldegiorgis ST, et al. Rice stress-resistant SNP database. Rice. 2019;12(1):1-12.

38. Portwood JL, et al. MaizeGDB 2018: the maize multi-genome genetics and genomics database. Nucleic Acids Res. 2019;47(D1):D1146-54.

39. Alaux $M$, et al. Linking the international wheat genome sequencing consortium bread wheat reference genome sequence to wheat genetic and phenomic data. Genome Biol. 2018;19(1):1-10.

40. Gelbart WM. Databases in genomic research. Science. 1998:282(5389):5659.

41. Kim NH, et al. Genome and evolution of the shade-requiring medicinal herb Panax ginseng. Plant Biotechnol J. 2018;16(11):1904-17.

42. Zhou G, Liao B. Brazilian pharmacopoeia genomic database. http://www. bpgenome.com. Accessed 20 Mar 2021.

43. Brandão MGL, et al. Medicinal plants and other botanical products from the Brazilian official pharmacopoeia. Revista Brasileira de Farmacognosia. 2006;16(3):408-20.

44. The Flora Reipublicae Popularis Sinicae. http://www.iplant.cn. Accessed 2 Aug 2019.

45. The Flora do Brasil. http://floradobrasil.jbrj.gov.br. Accessed 10 Oct 2020

46. National Center for Biotechnology Information. https://www.ncbi.nlm. nih.gov. Accessed 1 July 2019.

47. China National GeneBank DataBase. https://db.cngb.org. Accessed 1 July 2019.

48. Shen $\mathrm{X}$, et al. Complete chloroplast genome sequence and phylogenetic analysis of the medicinal plant Artemisia annua. Molecules. 2017:22(8):1330. 
49. Nakamura T, et al. Parallelization of MAFFT for large-scale multiple sequence alignments. Bioinformatics. 2018;34(14):2490-2.

50. Clustal Omega. http://www.clustal.org/omega. Accessed 10 Feb 2021.

51. EMBOSS SourceForge. http://emboss.sourceforge.net. Accessed 10 Feb 2021.

52. Brandão MG, Cosenza GP, Moreira RA, Monte-Mor RL. Medicinal plants and other botanical products from the Brazilian Official Pharmacopoeia. Braz J Pharmacogn. 2006;16:408-20.

53. Anvisa ANdVS. The second supplement of the Brazilian Pharmacopoeia, 5th edition. 2017.

54. Tabajara deO, Martins D, et al. The historical development of pharmacopoeias and the inclusion of exotic herbal drugs with a focus on Europe and Brazil. J Ethnopharmacol. 2019;240:111891.

55. Carvalho ACB, et al. The Brazilian market of herbal medicinal products and the impacts of the new legislation on traditional medicines. J Ethnopharmacol. 2018;212:29-35.

56. Matos FdA, et al. Constituintes químicos ativos e propriedades biológicas de plantas medicinais brasileiras. Fortaleza: Editora UFC; 2004

57. Brandão MGL, et al. Traditional uses of American plant species from the 1st edition of Brazilian Official Pharmacopoeia. Revista Brasileira de Farmacognosia. 2009;19:478-87.

58. Anvisa ANdVS. Brizilian Pharmacopoeia, 5th edition. Vol. 12010.

59. Leite PM, Camargos LM, Castilho RO. Recent progess in phytotherapy: a Brazilian perspective. Eur J Integr Med. 2021;41:101270.

60. Santos AC, et al. Current use of native medicinal species recorded by European Naturalists in the 19th century along the Royal Road, Minas Gerais, Brazil. Bioremediat Biodivers Bioavailab. 2011:5(1):113-6.

61. De Carvalho ACD. Feiticeiros, burlões e mistificadores: criminalidade e mudança das práticas populares de saúde em São Paulo, 1950 a 1980 São Paulo: Editora UNESP; 2003. p. 172.

62. Brandão MGL, et al. Influence of Brazilian herbal regulations on the use and conservation of native medicinal plants. Environ Monit Assess. 2010;164(1):369-77.

63. Carvalho $A C$, et al. Situação do registro de medicamentos fitoterápicos no Brasil. Revista Brasileira de Farmacognosia. 2008;18(2):314-9.

64. Fernandes TM. Plantas medicinais: memória da ciência no Brasil. Editora Fiocruz; 2004

65. Lucchesi G. Dependência e autonomia no setor farmacêutico: um estudo da CEME. 1991.

66. Manhã EM, et al. PLANT: a bibliographic database about medicinal plants. Revista Brasileira de Farmacognosia. 2008;18:614-7.

67. Brandão M, Montemor R. Sabedoria antiga em risco. Cienc Hoje. 2008:42:77-9.

68. Brandão MGL, et al. Other medicinal plants and botanical products from the first edition of the Brazilian Official Pharmacopoeia. Revista Brasileira de Farmacognosia. 2008;18:127-134.
69. Ricardo LM, et al. Plants from the Brazilian traditional medicine: species from the books of the Polish physician Piotr Czerniewicz (Pedro Luiz Napoleão Chernoviz, 1812-1881). Revista Brasileira de Farmacognosia. 2017;27(3):388-400.

70. Maiara M, Marianne Pinheiro T. A EXPANSÃO DA UTILIZAÇÃO DE FITOTERÁPICOS NO BRASIL. Anais do Salão Internacional de Ensino, Pesquisa e Extensão, 2020;9(2)

71. Brandao MG, et al. Brazilian medicinal plants described by 19th century European naturalists and in the Official Pharmacopoeia. J Ethnopharmacol. 2008;120(2):141-8.

72. Alencar NL, Santoro FR, Albuquerque UP. What is the role of exotic medicinal plants in local medical systems? A study from the perspective of utilitarian redundancy. Revista Brasileira de Farmacognosia. 2014;24(5):506-15.

73. Chen $\mathrm{S}$, et al. A renaissance in herbal medicine identification: from morphology to DNA. Biotechnol Adv. 2014;32:1237-44.

74. Gilbert, Natasha. Herbal medicine rule book. Nature. 2011;480:22-9.

75. Poon WT, et al. Aconite poisoning in camouflage. Hong Kong Acad Med. 2006;12(6):456-9.

76. Lowe L, Matteucci MJ, Schneir AB. Herbal aconite tea and refractory ventricular tachycardia. N Engl J Med. 2005;353(14):1532.

77. Chan T. Incidence of herb-induced aconitine poisoning in Hong Kong. Drug Saf. 2002;25(11):823-8.

78. Han J, et al. An authenticity survey of herbal medicines from markets in China using DNA barcoding. Sci Rep. 2016;6:(18723).

79. Dean W. A ferro e fogo: a história e a devastação da Mata Atlântica brasileira. São Paulo: Companhia das Letras; 1996. p. 484.

80. Patricia S, Araújo RNd. Conhecimento em Erosão: Um Invetário Etnobotânico na Fronteira de Exploração da Amazônia Oriental. Boletim do Museu Paraense Emílio Goeldi. 2005;1:147.

81. Chen S, et al. Herbal genomics: examining the biology of traditional medicines. Science. 2015;347(6219):S27-9.

82. Dong $L-L$, et al. DNA marker-assisted selection of medicinal plants (I). Breeding research of disease-resistant cultivars of Panax notoginseng. China J Chin Materia Med. 2017;42(1):56-62.

83. Shen $\mathrm{Q}$, et al. Medicinal plant DNA marker assisted breeding (II) the assistant identification of SNPs assisted identification and breeding research of high yield Perilla frutescens new variety. China J Chin Materia Med. 2017:42(9):1668-72

\section{Publisher's Note}

Springer Nature remains neutral with regard to jurisdictional claims in published maps and institutional affiliations.
Ready to submit your research? Choose BMC and benefit from:

- fast, convenient online submission

- thorough peer review by experienced researchers in your field

- rapid publication on acceptance

- support for research data, including large and complex data types

- gold Open Access which fosters wider collaboration and increased citations

- maximum visibility for your research: over 100M website views per year

At BMC, research is always in progress.

Learn more biomedcentral.com/submissions 